\title{
PLANT REGENERATION THROUGH TISSUE CULTURE OF PEAR MILLET (Pennisetum Glaucum (L) R.)
}

\author{
K.TIECOURA ${ }^{1}$, L. LEDOUX. ${ }^{2}$ AND M. DINANT. ${ }^{2}$ \\ ${ }^{1}$ Laboratoire de Génétique et amélioration des plantes, UFR de Biosciences, Université de Cocody, \\ B.P.582 Abidjan 22, Côte d'Ivoire. \\ ${ }^{2}$ Laboratoire de Génétique Moléculaire, Département de Botanique, Université de Liège, Sart Tilman \\ B22, B-4000 Liège, Belgium.
}

\begin{abstract}
.
Many problems were kipt out with immature embryos and shoot explants pieces used ; principally : Calli were initiated in plant flowering periode (every 110 days), and the low percentage of embrogenesis what either the source used. So for Pennisetum glaucum, new embryogenic calli sources were explored from calli initiation to fertile plant regeneration achieving. About $90 \%$ of dissected shoot apices, seedlings and seeds developed calli. From meristems position, $6 \mathrm{~mm}$ of shoot and $20 \mathrm{~mm}$ of root developed 50 to $100 \%$ of calli. No embryogenic calli were obtained from root. More than $80 \%$ of dissected apices led to embryogenic calli. Maintained on MS(1. 1. 2,5), MS(5) and N6(1.100.25) culture media, calli embryogenic potential and fertile plants regeneration were conserved for more than 12 months. Characteristics of regenerated plants were similar to control. It appears that dissected shoot apex was a new appropriate tool in tissue culture.
\end{abstract}

Key words: Tissue culture, culture medium, callus induction, shoot apex, Pennisetum glaucum, Côte d'Ivoire.

RESUME.

\author{
REGENERATION DE PLANTE A PARTIR DE LA CULTURE DE TISSUS DE MIL (Pennisetum \\ glaucum $(L) R$.)
}

Les difficultés liées à utilisation de l'embryon immature et des explants de tige dans les cultures de tissus sont nombreuses; dont l'initiation de cal qui ne se fait que pendant la floraison, pour l'embryon immature, soit chaque 110 jours, et le faible pourcentage de l'embryogenèse. Pour Pennisetum glaucum , de nouvelles sources de cals embryogènes ont été explorées depuis l'initiation de cal jusqu'à l'obtention de plante fertile. Environ $90 \%$ des méristèmes apicaux, des germes et des grains ont développé des cals. A partir des méristèmes, seuls $6 \mathrm{~mm}$ de tige et $20 \mathrm{~mm}$ de racine ont développé des cals avec un taux de 50 à $100 \%$. La racine n'a développé aucun cal embryogène. Plus de $80 \%$ des cals de méristèmes apicaux étaient embryogènes. Les cals maintenus sur MS(1.1.2,5), MS(5) et N6(1.100.25), sont restés embryogènes et ont produit des plantes fertiles pendant au moins 12 mois. Les plantes régénérées ont des caractéristiques semblables aux plantes témoins. Il ressort que le méristème apical est un nouveau matériel approprié pour la culture de tissus.

Mots clés: culture de tissus, milieu de culture, induction de cal, méristème apical, Pennisetum glaucum, Côte d'lvoire. 


\section{INTRODUCTION}

Achieving crop improvement through genetic biotechnology requiered tissue culture with subséquent regeneration of fertile plants. The first investigations, of tissue culture, on Hordeum vulgare (KOBLITZ and Saalbaack 1976 ; DALE and Deambrogio 1979) and on Lolium multiforum (DALE 1977) have shown that graminea dissected shoot apex was not appropriate for tissue culture because it necrotized.

During the last decade, new sources of calli were than explored to improve cereal and grass tissue culture. Today, for the important cereals and grasses, plant regeneration was reported: With somatic embryogenesis from young inflorescences and mature seeds of Panicum maximum (CHIN-YI and Vasil 1981), Triticum aestivum (OZIAS and Vasil 1982), Paspalum scrobiculatum (NAYAK and Sen 1989), Oryza sativa (Yao, 1998) and from young leaves of Pennisetum purpureum (Haydu and Vasil 1981 ; RAJASE-KARAN et al, 1987). Concerning Pennisetum glaucum, plant was regenerated with embryoid formation from immature embryos (VASIL and Vasil 1981, 1982a); as well as young inflorescences (VASIL and Vasil 1982b), or from excised shoot explant pieces of 4 to 5 days old plants (BOTTI and Vasil 1983 ; Lambé et al 1999).

In immature embryos, young inflorescences and shoot explants pieces utilization, many problems were kept out with these most evoked : The waiting of flowering periode befor initiating calli (every 110 days) and the low percentages of embrogenesis of these sources. In the present paper, different explants, principally shoot dissected . . . ... . . glaucum tissue culture improvement. Since the unsuccessful experiments of KOBLITZ and Saalbaack (1976), DALE and Deambrogio (1979) mention above, no studies from dissected shoot apex was reported yet.

\section{MATERIALS AND METHODS}

\section{Plant materials}

Four Pennisetum glaucum varieties (NE, CN, NW and SR1) cultivated in Côte d'Ivoire were used.

Seeds and seedlings (two to four days old), dissected shoot apex of these seedlings (figure $4: a$ ), small segments $(2-5 \mathrm{~mm})$ of main root or shoot of 10 and 20 days old plantlets, immature embryos sampled 5-7 days after pollination and, control, and regenerated plants were used for these studies.

\section{Culture media}

MS and N6 media were used with followed modifications. 2,4D (2,4dichlorophenoxyacetic acid), BAP (6benzylaminopurine), NAA (naphtalene1-acetic acid), proline and caseine hydrolysat were added (table 1). 
Table 1 : The composition of MS (Murashig and Skoog, 1962) and N6(Chu,1978) Media used in vitro culture of Pennisetum glaucum.

\begin{tabular}{|c|c|c|}
\hline \multirow[t]{2}{*}{ Components } & \multicolumn{2}{|c|}{ Composition of MS and N6 Media } \\
\hline & MS & N6 \\
\hline \multicolumn{3}{|c|}{ Macro-elements (g/l) } \\
\hline $\mathrm{NH} 4 \mathrm{NO} 3$ & 1,65 & - \\
\hline KNO3 & 1,9 & 2,83 \\
\hline $\mathrm{CaCl} 22 \mathrm{H} 2 \mathrm{O}$ & 0,44 & 0,166 \\
\hline $\mathrm{MgSO} 47 \mathrm{H} 2 \mathrm{O}$ & 0,37 & 0,185 \\
\hline $\mathrm{KH} 2 \mathrm{PO} 4$ & 0,17 & 0,4 \\
\hline$(\mathrm{NH} 4) 2 \mathrm{SO} 4$ & - & 0,463 \\
\hline \multicolumn{3}{|c|}{ Micro-elements (mg / l ) } \\
\hline $\mathrm{H} 3 \mathrm{BO} 3$ & 6,2 & 1,6 \\
\hline $\mathrm{MnSO} 4 \mathrm{H} 2 \mathrm{O}$ & 16,9 & 3,3 \\
\hline ZnSO4 7H2O & 8,6 & 1,5 \\
\hline $\mathrm{Na} 2 \mathrm{MoO} 42 \mathrm{H} 2 \mathrm{O}$ & 0,25 & - \\
\hline CuSO4 5H2O & 0,025 & - \\
\hline $\mathrm{CoCl} 26 \mathrm{H} 2 \mathrm{O}$ & 0,025 & 0,025 \\
\hline $\mathrm{KI}$ & 0,83 & 0,83 \\
\hline \multicolumn{3}{|l|}{ FeEDTA (mg / l ) } \\
\hline Na2EDTA & 37 & 37,3 \\
\hline $\mathrm{FeSO} 47 \mathrm{H} 2 \mathrm{O}$ & 27,8 & 27,8 \\
\hline \multicolumn{3}{|l|}{ Vitamines (mg / ) } \\
\hline Thiamine $\mathrm{HCl}$ & 0,5 & 1 \\
\hline Pyridoxine $\mathrm{HCl}$ & 0,5 & 0,5 \\
\hline Nicotinic Acid & 0,05 & 0,5 \\
\hline Myoinositol & 100 & 100 \\
\hline \multicolumn{3}{|c|}{ Other elements $(\mathrm{g} / \mathrm{l})$} \\
\hline Glycine & 0,002 & 0,002 \\
\hline Sucrose & 30 & 50 \\
\hline
\end{tabular}


Table 2 : Different media used for Pennisetum glaucum tissue culture.

\begin{tabular}{|c|c|c|c|c|c|}
\hline medium & $\begin{array}{l}\text { NAA } \\
\mathrm{mg} / \mathrm{I}\end{array}$ & $\begin{array}{l}\text { BAP } \\
\mathrm{mg} / \mathrm{I}\end{array}$ & $\begin{array}{l}2,4 \mathrm{D} \\
\mathrm{mg} / /\end{array}$ & $\begin{array}{c}\text { caseine } \\
\text { hydrolysat } \\
\text { mg / I }\end{array}$ & $\begin{array}{c}\text { proline } \\
\mathrm{mM}\end{array}$ \\
\hline MS (1. 0,5.0,5) & 1 & 0,5 & 0,5 & - & - \\
\hline MS (1. 1. 1) & 1 & 1 & 1 & - & - \\
\hline $\operatorname{MS}(0,5.1 .2)$ & 0,5 & 1 & 2 & - & - \\
\hline MS (1. 0,5. 2,5) & 1 & 0,5 & 2,5 & - & - \\
\hline MS (1. 1. 2,5) & 1 & 1 & 2,5 & - & - \\
\hline MS (5) & - & - & 5 & - & - \\
\hline MS $(0,5.2)$ & 0,5 & 2 & - & - & - \\
\hline N6 (1. 100. 25) & - & - & 1 & 100 & 25 \\
\hline
\end{tabular}

\section{Sterilisation}

Seeds and immature embryos were surface-sterilised with $95 \%(\mathrm{v} / \mathrm{v})$ $\mathrm{C} 2 \mathrm{H} 2 \mathrm{OH}$ and $3 \%(\mathrm{v} / \mathrm{v}) \mathrm{H} 2 \mathrm{O} 2$ mixed in a $1: 1$ ratio for $5 \mathrm{~min}$. Followed, for seeds only, by a 1 and half minite shaking in 50 $\%$ (v/v) H2SO4. They were abundantly rinsed with sterile distilled water ; then sterilized one more time with the ethanolhydrogen peroxyd mixture for 6 or 10 min , and abundantly rinsed with sterillized distiled water and used for experiments.

\section{Calli induction}

After 20 days, no main root could be distinguished. So, 150 main roots of 10 and 20 days old plants were cut into segments of $5 \mathrm{~mm}$ in length from the tip. Each fragments was tested for 7 days on MS (5), MS (1.1.2,5) and N6 (1.100.25) media in PETRI boxes. The percentages of fragments that developped calli were recorded. 150 shoots of 10 and 20 days old plants were cut into segments of $2 \mathrm{~mm}$ in length from the meristem and cultured for 7 days on MS(5), MS(1.1.2,5) and N6(1.100.25). The percentages of developping calli fragments were determined. 150 seeds, 60 seedling, 60 dissected shoot apex and 90 immature embryos were tested for 7 days on $\mathrm{MS}(5), \mathrm{MS}(1.1 .2,5)$ and N6(1.100.25) media. The percentages of developping calli explants were also reported.

\section{Embryogenesis design}

Two types of calli were observed : The first type, with wet surface, whitish, smooth and translucent, were nonembryogenic calli and led not to plant (figure $4: b$, e (nec)). The second type of calli, yellowish, generally rough and dry, either friable or compact, were embryogenic calli and regenerated plants (figure 4 : c, e (ec)). For each source of calli, embryogenesis and stability improvement were followed. So

100 calli of seedlings, 50 calli of shoots $(0-2 \mathrm{~mm}), 70$ calli of immature embryos, 90 calli dissected apex, and 100 calli of roots induced on medium 
MS(1.1.2,5) were subcultured every 15 days for 5 subcultures because after, no more embryogenesis was observed. The cumulate percentage of embryogenic calli were reported. For the effect of $2,4 \mathrm{D}$ on totally embryogenic calli improvement, 50, 81, 84, 85, 57 and 97 dissected apices were cultured for 45 days on MS medium supplemented with respectivly $0,0,5,1,2,3$ and $5 \mathrm{mg} / \mathrm{l}$ of $2,4 \mathrm{D}$. The percentages of embryogenic calli and totally embryogenic calli were determined. Concerning the effect of BAP and NAA on totally embryogenic calli improvement, 300 dissected apices were tested on MS $(0,5.1 .2)$, MS $(1.0,5.0,5), \mathrm{MS}(1.0,5.2,5), \mathrm{MS}(1.1 .1)$ and MS (1.1.2,5) media (60 dissected apices per medium). The percentage of embryogenic calli and totally embryogenic calli were reported. Embryogenic calli growth was followed with the weight of 60 embryogenic calli cultured for 8 weeks (subculture every two weeks) on MS(1.1.2,5), MS(5) and N6(1.100.25) calli maintaining media ; either 20 embryogenic calli per medium.

\section{Fertile plant regeneration}

Embryogenic calli maintained on MS(1.1.2,5), MS(5) and N6(1.100.25) media. They were used for fertile plant regeneration designing. So: The influence of calli age on plant regeneration was studied as followed : after 3, 6, 12 and 15 months, 20 embryogenic calli were sampled and transfered on MS $(0,5.2)$ medium for four weeks. The percentage of calli showing plants were reported. The action of maintaining medium on the cinetic of plant regeneration was determined as followed : 59,55 , and 57 embryogenic calli of three months old sampled respectively from MS $(1.1 .2,5), M S(5)$ and N6 (1.100.25) media have regenerated plantlets for 4 weeks on MS(0,5.2). Every week, fresh regeneration medium was used. The cumulate percentage of calli showing plants were reported. For the plant fertility studies, regenerated (30) and control (15) plants of the four Genotype (NE, NW, CN and SR1) were grown, in pot of $10 \mathrm{~cm}$ of diameter containing soil $(1 / 3)$ and mould (2 / 3), in greenhouse at $25^{\circ} \mathrm{C}$ with $16 \mathrm{~h}$ of light/day (120-144 uEs- $\left.{ }^{-1} \mathrm{~m}^{-2}\right)$ for 50 or 60 days. After 60 days, exposition to light was adjusted to $12 \mathrm{~h} /$ day to ensure flowering and harvest. Data of some parameters were noted : plant height $(\mathrm{cm})$, bare number, candle length $(\mathrm{cm})$, spike length $(\mathrm{cm})$ and seed number per spike.

\section{Data analysis}

For statistical analysis, the chi $\left(\mathrm{X}^{2}\right)$ test, percentages comparison and averages comparison methods were used.

\section{RESULTS}

\section{Calli induction}

\section{Root explants}

For the $5 \mathrm{~mm}$ from each tip, 100 $\%$ of callus was obtained (fig. 4 b). This rate decreased gradually along the root ( $75-10 \%$ ) to reach $0 \%$ after $30 \mathrm{~mm}$. No significative difference was observed between 10 or 20 days old plants, whatever the callus inducing medium, neither between the tree media. 
Table 3: Percentage of induced calli with fragments of roots from 10 and 20 days old plants.

\begin{tabular}{crrrrrr}
\hline & \multicolumn{2}{l}{$\begin{array}{l}\text { Induced root calli from } 10 \text { and } 20 \text { days old } \\
\text { plants, in MS(5), MS(1.1.2,5) and N6(1.100.25) media (\%) }\end{array}$} \\
\cline { 2 - 7 } $\begin{array}{c}\text { distance of } \\
\text { fragment from }\end{array}$ & \multicolumn{2}{c}{ MS(5) } \\
apex (mm) & 10 & 20 & 10 & 20 & 10 & 20 \\
\hline $00-05$ & 100 & 100 & 100 & 100 & 100 & 100 \\
$05-10$ & 74 & 70 & 73 & 68 & 77 & 70 \\
$10-15$ & 63 & 59 & 65 & 60 & 65 & 62 \\
$15-20$ & 48 & 49 & 50 & 50 & 51 & 50 \\
$20-25$ & 35 & 21 & 34 & 19 & 37 & 20 \\
$25-30$ & 20 & 8 & 20 & 12 & 22 & 12 \\
$30-35$ & 00 & 00 & 00 & 00 & 00 & 00 \\
$35-40$ & 00 & 00 & 00 & 00 & 00 & 00 \\
\hline
\end{tabular}

Table 4 : Percentage of induced calli with fragments of shoots from 10 and 20 days old plants.

\begin{tabular}{|c|c|c|c|c|c|c|}
\hline \multirow{3}{*}{$\begin{array}{c}\text { Distance of } \\
\text { fragment from } \\
\text { apex }(\mathrm{mm})\end{array}$} & \multicolumn{6}{|c|}{$\begin{array}{l}\text { Induced shoot calli from } 10 \text { and } 20 \text { days old plants, in MS(5) } \\
\text { MS(1.1.2,5) and N6(1.100.25) media (\%) }\end{array}$} \\
\hline & \multicolumn{2}{|c|}{$\mathrm{MS}(5)$} & \multicolumn{2}{|c|}{$\mathrm{MS}(1 \cdot 1 \cdot 2,5)$} & \multicolumn{2}{|c|}{ N6(1.100.25) } \\
\hline & 10 & 20 & 10 & 20 & 10 & 20 \\
\hline $00-02$ & 100 & 100 & 100 & 100 & 100 & 100 \\
\hline $02-04$ & 100 & 100 & 100 & 100 & 100 & 00 \\
\hline 04-06 & 61 & 50 & 59 & 49 & 62 & 52 \\
\hline $06-08$ & 36 & 32 & 40 & 30 & 43 & 33 \\
\hline $08-10$ & 30 & 10 & 28 & 12 & 31 & 10 \\
\hline $10-12$ & 15 & 05 & 15 & 04 & 17 & 07 \\
\hline $12-14$ & 05 & 00 & 05 & 00 & 05 & 00 \\
\hline $14-16$ & 00 & 00 & 00 & 00 & 00 & 00 \\
\hline $16-18$ & 00 & 00 & 00 & 00 & 00 & 00 \\
\hline
\end{tabular}




\section{Shoot explants}

Growing calli were induced up to $12 \mathrm{~mm}$ for old plants and up to $14 \mathrm{~mm}$ for young plants. Agradiant in callus induction was observed. From $100 \%$ of callus in meristematic region $(0-4 \mathrm{~mm})$; this rate decreased, quickly, from this area (example: 62 to $5 \%$ througth 12 $\mathrm{mm}$ ). It decreased faster as the plant got older: at $10 \mathrm{~mm}, 30 \%$ of 10 days old plants produced callus, versus $10 \%$ from 20 days old plants. In any case, no significant difference was observed on the 3 tested media.

\section{Other sources for calli induction}

Table 5 : Percentage of induced calli from explants of seed, seedling, dissected apex and immature embryos.

\begin{tabular}{lccc}
\hline & \multicolumn{3}{c}{ Induced calli, in each medium (\%) } \\
\cline { 2 - 4 } Origine of explant & MS(5) & MS(1.1.2,5) & N6(1.100.25) \\
\hline seeds & 75 & 88 & 82 \\
seedling & 99 & 95 & 100 \\
dissected apex & 95 & 85 & 97 \\
immature embryos & 50 & 44 & 55 \\
\hline
\end{tabular}

Callus induction occured frequently in these other types of materials (80-90\%), except for immature embryos $(50 \%)$. We noted the high callus inducing potential of dissected shoot apex $(90 \%)$. For each explant used, no significative difference was observed between the three callus inducing media used.

\section{Embryogenic calli and stability}

\section{Embryogenic calli harvested through subcultures}

Table 6 : Percentage of Somatic embryogenesis of seedling, shoot (0-2mm), immature embryos, dissected apex and root callus followed by five subcultures.

\begin{tabular}{|c|c|c|c|c|c|}
\hline \multirow[b]{2}{*}{ different explants } & \multicolumn{4}{|c|}{$\begin{array}{l}\text { percentage of somatic embryogenesi } \\
\text { for five subcultures }\end{array}$} & \multirow[b]{2}{*}{5} \\
\hline & $\overline{1}$ & 2 & 3 & 4 & \\
\hline seedling & 00 & 05 & 15 & 30 & 35 \\
\hline $\operatorname{shoot}(0-2 \mathrm{~mm})$ & 00 & 10 & 50 & 60 & 60 \\
\hline immature embryos & 00 & 02 & 04 & 08 & 16 \\
\hline dissected apex & 00 & 50 & 80 & 90 & 90 \\
\hline root & 00 & 00 & 00 & 00 & 00 \\
\hline
\end{tabular}


It appeared that, root did not developp embryogenic calli through subcultures (0\%) (fig. 4 b). Embryogenesis induction increased with subcultures whatever the origine of calli. About $16 \%$ of immature calli evoluated into embryogenic calli, followed by $35 \%$ of seedlings' calli, followed by $60 \%$ of shoot's calli and followed by $90 \%$ of dissected apex calli. Embryogenic calli were either totally embryogenic (fig. 4 c), or a mixture (fig. 4 e). Almost $90 \%$ of dissected meristems developed embryogenic calli.

\section{Effect of 2,4D on totally embryogenic calli improvement}

Table 7 : Percentage of embryogenic calli with 2,4D concentration (mg/l).

\begin{tabular}{lllllll}
\hline & \multicolumn{5}{c}{ percentage of embyogenic calli according to } \\
& \multicolumn{6}{c}{ concentration(mg/l). } \\
\cline { 2 - 7 } Types of calli induced & 0 & 0,5 & 1 & 2 & 3 & 5 \\
\hline \multirow{2}{*}{ embryogenic calli } & 0 & 89 & 92 & 89 & 90 & 91 \\
totally embryogenic calli & 0 & 40 & 50 & 65 & 94 & 95 \\
\hline
\end{tabular}

No callus was observed without $2,4 \mathrm{D}$. Shoot apex necrosed or developed plantlet. To induce callus, 0,5 $\mathrm{mg} / \mathrm{l}$ of $2,4 \mathrm{D}$ was needed. The rate of embryogenic calli (mixture callus) was high (88 to $92 \%$ ) whatever the $2,4 \mathrm{D}$ concentration. But totally embryogenic calli rate increased with the increasing of the auxin concentration, to reach $95 \%$ with $3-5 \mathrm{mg} / \mathrm{l}$ of $2,4 \mathrm{D}$.

Effect of BAP and NAA on totally embryogenic callo improvement

TAble 8 : Percentage of embryogenic calli of five media with NAA and BAP.

\begin{tabular}{lccccc}
\hline & \multicolumn{5}{c}{ percentage of embyogenic calli for five media. } \\
\cline { 2 - 6 } Types of calli induced & MS(1.0,5.0,5) & MS(1.1.1) & MS(0,5.1.2) & MS (1.0,5.2,5) & MS $(1.1 .2,5)$ \\
\hline embryogenic calli & 91 & 95 & 100 & 96 & 90 \\
totally & 90 & 95 & 90 & 90 & 92 \\
\hline
\end{tabular}


NAA and BAP added improved significantly callus embryogenesis. With $1 \mathrm{mg} / \mathrm{l}$ and $2 \mathrm{mg} / \mathrm{l}$ of 2,4D, $50 \%$ and $65 \%$ of totally embryogenic calli were respectively obtained (table 7 ), against respectively $95 \%$ and $90 \%$, when NAA and BAP were added (MS(1.1.1) and $M S(0,5.1 .2))$. Whatever NAA and BAP concentra- tion, the totally embryogenic calli was high ( about $90 \%$ ) and non significantly different ; so, The effect of NAA and BAP combination was more assigned to their presence than to their concentration. When NAA, BAP and 2,4D were added to a medium, both growth and embryogenic characters were kept through the subcultures.

\section{Embryogenic calli growth}

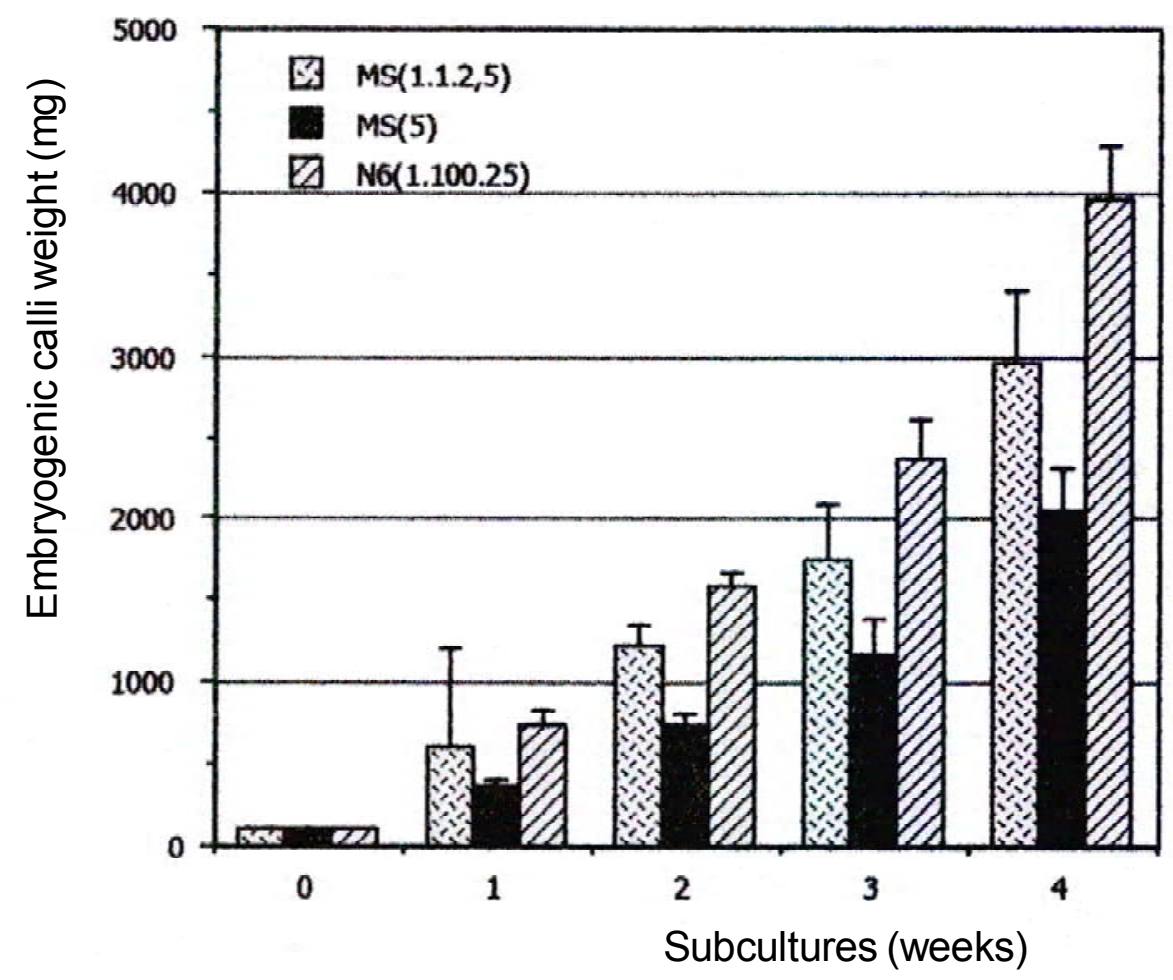

Figure 1 : Embryogenic calli's weight $(\mathrm{mg})$ through subcultures as a function of media.

With four subcultures, embryogenic calli weight passed from $300 \mathrm{mg}$ to $2000 \mathrm{mg}$, from $500 \mathrm{mg}$ to $3000 \mathrm{mg}$ and from $700 \mathrm{mg}$ to 4000 $\mathrm{mg}$ respectvely on $\mathrm{M}(5), \mathrm{MS}(1.1 .2,5)$ and N6 (1.100.25). It was clear that embryogenic calli weight regulary augmented whatever the maintaining medium considered. But this weight augmentation was lightly low on MS(5) medium. 


\section{FERTILE PLANT REGENERATION}

\section{Age of calli and plant regeneration}

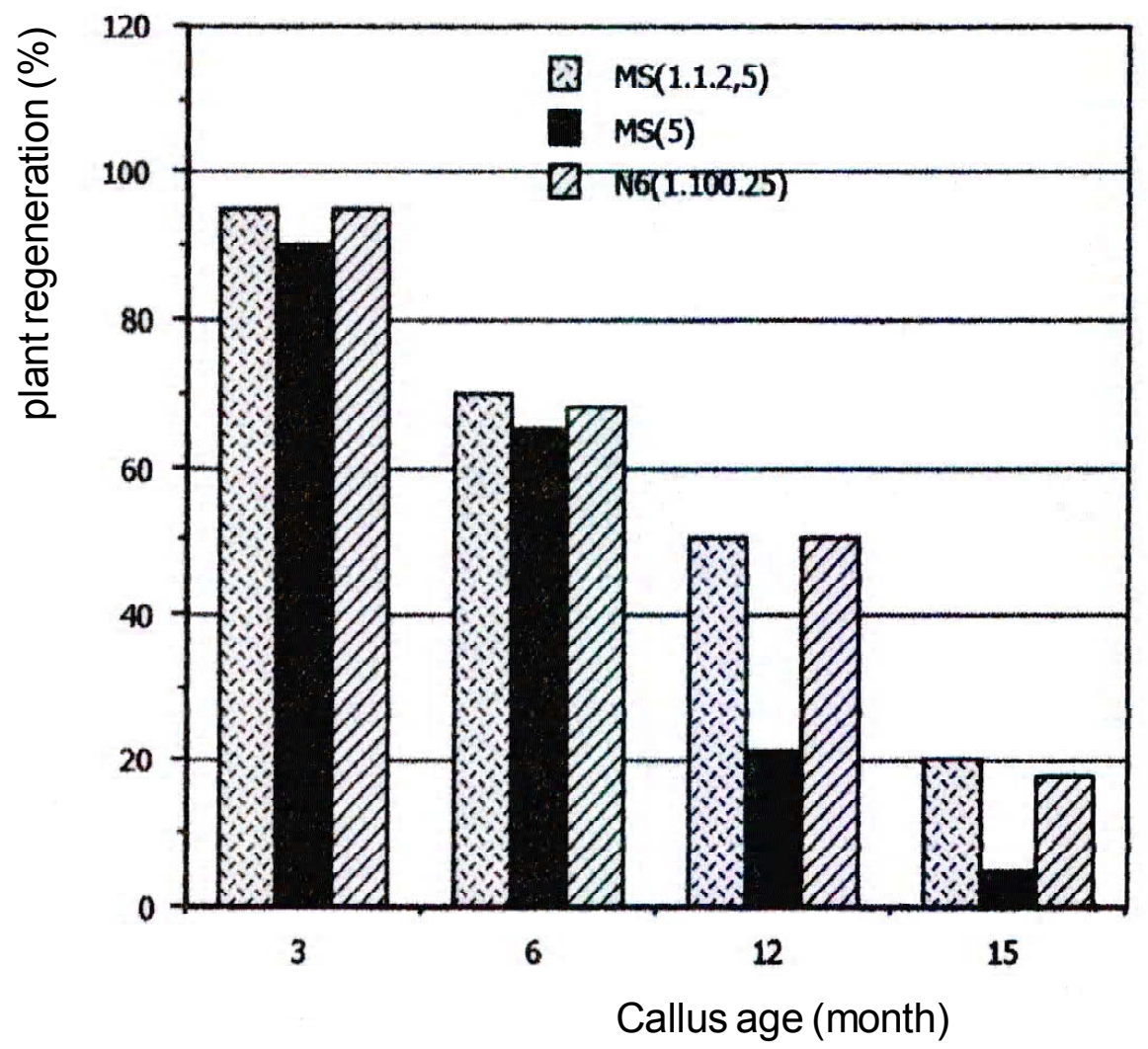

Figure 2 : Evolution of the percentage of plant regeneration as a function of callus age.

The percentage of plant regeneration passed from $95,70,50$ to 20 respectively with $3,6,12$ and 15 month old calli deriving from MS(1.1.2,5) or N6(1.100.25). For MS(5), these percentages were $90,65,20$ to 5 with $3,6,12$ and 15 month old calli respectively. For each maintaining medium, it was so established that calli developed plants still more than 15 months. The plant regeneration rate was high for calli of about three months old ; but decreased gradually with calli age. For MS (5) medium, the rate was rapidly lowering after six months. 


\section{Calli maintaining media and cinetic of plant regeneration}

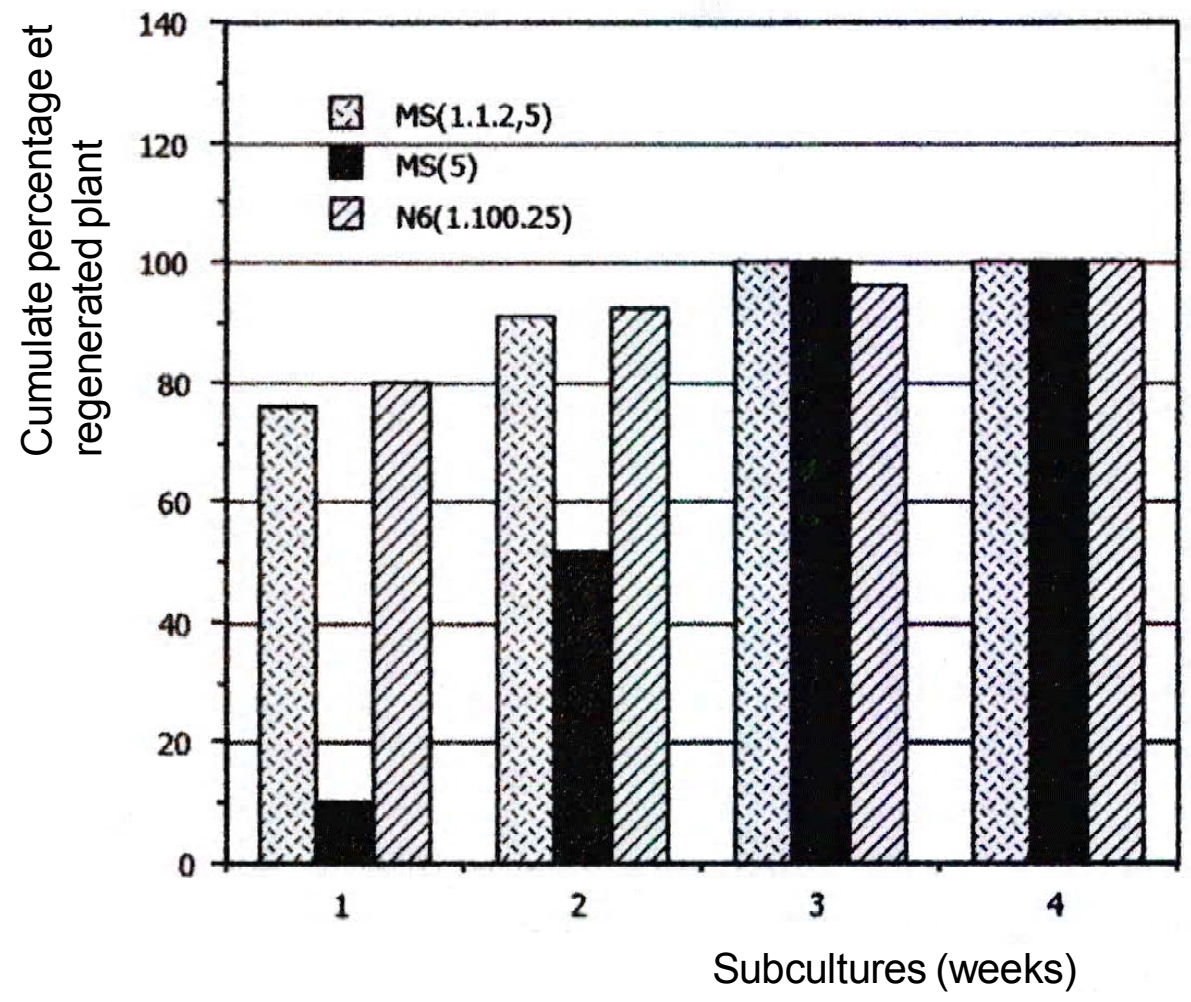

Figure 3 : Cumulate percentage of regenerated plant as a function of media.

The cumulate percentage of calli with plant passed from 80,90 to 100 respectively after 1,2 and 3 weeks, with calli deriving from MS(1.1.2,5) or N6(1.100.25). For MS(5), these percentages were 10 ,
50,95 to 100 after $1,2,3$ and 4 weeks respectively. It was clear that one week was needed for majority of calli of MS $(1.1 .2,5)$ and N6 $(1.100 .25)$ to regenerate plant, versus 3 weeks for calli of MS(5). 


\section{Regenerated and control plants data}

Table 9 : Some data of mature regenerated and control plants.

\begin{tabular}{lllllll}
\hline \multirow{2}{*}{$\begin{array}{l}\text { Genotype } \\
\text { of plant }\end{array}$} & \begin{tabular}{l} 
Degenerated \\
and control \\
\cline { 3 - 6 }
\end{tabular} & $\begin{array}{l}\text { Plant } \\
\text { peight } \\
(\mathrm{cm})\end{array}$ & $\begin{array}{c}\text { Bare } \\
\text { number }\end{array}$ & $\begin{array}{c}\text { Candle } \\
\text { length } \\
(\mathrm{cm})\end{array}$ & $\begin{array}{c}\text { Spike } \\
\text { length } \\
(\mathrm{cm})\end{array}$ & $\begin{array}{l}\text { Seed } \\
\text { number by } \\
\text { spike }\end{array}$ \\
\hline NE & control & $200 \pm 4$ & $18 \pm 2$ & $31 \pm 1$ & $9 \pm 2$ & $715 \pm 195$ \\
& regenerated & $180 \pm 3$ & $20 \pm 4$ & $30 \pm 2$ & $12 \pm 1$ & $412 \pm 278$ \\
\cline { 2 - 7 } SR1 & control & $200 \pm 6$ & $16 \pm 2$ & $37 \pm 1$ & $13 \pm 1$ & $681 \pm 206$ \\
& regenerated & $220 \pm 4$ & $17 \pm 5$ & $33 \pm 2$ & $15 \pm 1$ & $337 \pm 270$ \\
\cline { 2 - 7 } CN & control & $220 \pm 5$ & $17 \pm 4$ & $35 \pm 1$ & $13 \pm 2$ & $431 \pm 353$ \\
& regenerated & $200 \pm 3$ & $17 \pm 5$ & $30 \pm 1$ & $11 \pm 1$ & $474 \pm 301$ \\
\cline { 2 - 7 } NW & control & $200 \pm 5$ & $17 \pm 3$ & $30 \pm 1$ & $12 \pm 1$ & $488 \pm 126$ \\
& regenerated & $180 \pm 4$ & $16 \pm 2$ & $30 \pm 3$ & $10 \pm 1$ & $435 \pm 320$ \\
\hline
\end{tabular}

Flowering was observed after 55 or 67 days (fig $4 \mathrm{~h}$ ). Fertile (fig $4 \mathrm{i}$ (fs)) and non fertile (fig $4 \mathrm{i}$ (nfs) spikes were produced. Regenerated plants were heigher $(220 \mathrm{~cm})$ than controls $(200 \mathrm{~cm})$ for SR1 genotype; but for the other genotypes, controls were heigher (200 $\mathrm{cm})$ than regenerated plants $(180 \mathrm{~cm})$. The same seed number for controls and regenerated plants was observed for $\mathrm{CN}$ and NW genotypes (about 400); but for NE and SR1 genotypes, this number was more important for controls (about 700) than regenerated plants (about 400). The high standard deviation observed with seed number showed the great varibility of fertility. This variability was probably due to different light variations of culture conditions in green house. No significant statistic, between the controls and the regenerated plants, was observed for the other data : bare number (16 to 20 ), candle length $(30$ to $37 \mathrm{~cm})$ and spike length (9 to $15 \mathrm{~cm}$ ).

\section{DISCUSSION}

Dale and Deambrogio (1979) reported with Hordeum vulgare that root's tip $(0-10 \mathrm{~mm})$ induced callus. They observed no callus with $1 \mathrm{mg} / \mathrm{I}$ of 2,4D in medium ; but with $5 \mathrm{mg} / \mathrm{I}$ of 2,4D, lower than $50 \%$ of calli were induced. For Pennisetum glaucum, it was establish that $30 \mathrm{~mm}$ explants from roots can develop callus and with $10 \mathrm{~mm}$, more than $70 \%$ of calli were obtained. Here $1 \mathrm{mg} / \mathrm{l}$ of $2,4 \mathrm{D}$ was enough contrary to what was observed for Hordeum vulgare by Dale and Deambrogio (1979). Root tip was exclusively with 
meristematic totipotent cells, witch cells gave calli, hence root tip's high rate of callus induction. After the root tip, the other root explants contained less and less of meristematic cells, hence their low rate of callus induction. Beyond 30 $\mathrm{mm}$, no callus was observed because, beyond this distance, root explants had no meristematic cells. This experience showed up graminea cell dedifferentiation problem : In graminea, differentiated cells could not retern to meristematic stage even with growth hormone. The shoot meristem running followed the same principle as the root as described above. Beyond $10 \mathrm{~mm}$, callus inducing was low with shoot explant, so cell differentiation speed was higher in shoot than in root.

Seed, seedling, dissected apex and immature embryos developed callus because they contained meristematic cells. The sensibility to sterilization method could explain the difference between percentage of seed and seedling callus induction. Factors could explain the low percentage of immature embryos callus induction: The age, for embryos younger than 7 days, the rate was low ; the dissection method, wounded embryos could not lead to callus; sensibility to sterilization method could low callus percentage too. Botti et al (1983) on P. glaucum seedling did the same observations. Our rates were better (44-55 \%) than those obtained by Lambé et al (1999)(12-45 \%) in regard to these factors. But for both, immature embryos were less callus inducing than the other callus sources.

For $P$. glaucum, embryogenic callus was the only mean to regenerate plant. After 15-30 days of culture, dissection of non - embryogenic calli of seed and seedling (figure $4: d$ ) showed a meristem dome at quiescent stage. The dome remained still in the original state ; but free, it led to embryogenic callus (fig $4: \mathrm{c}$ ). After 15-30 days of culture, embryogenic calli of seed and seedling dissected did not show meristem dome. And, the embryogenic callus mass was in the meristem area. It was clear that shoot apex cells were the source of embryogenic calli in $P$. glaucum. Rapid proliferation of non embryogenic cells slowed down or blocked meristem dome cells development, and thus could explain the low percentage of embryogenic calli in seed, seedling and immature embryos. For immature embryos, the difference observed by Lambé et al (1999) between NE, NW and $\mathrm{CN}$ varieties was more due to embryos maturation stage than to the genotype as they pretend (Tiecoura, 1995).

Above $3 \mathrm{mg} / \mathrm{I}, 2,4 \mathrm{D}$ could be toxic for cells growth and so, it slowed down their proliferation ; particulary for non-embryogenic cells and led to a high rate of totally embryogenic callus (Table 7). In combining NAA and BAP with low 2,4D concentrations, embryogenic callus characters were maintained (table 8). Two facts have led our experiments : $2,4 \mathrm{D}$ was callus inducing and growth hormone. Both NAA and BAP led to complete plant regeneration (Nayak, 1989). With NAA alone, callus initiated roots mainly; with BAP alone, callus led to plants which were rooted with NAA (Tiecoura, 1995). It was clear that conbination of NAA, BAP and 2,4D changed the cell physiology ; and then, interference between plant regeneration and callus growth was observed. The interference of both phenomena could explain the growth and embryogenic characters keeping through subcultures (figure 1).

Concerning green plants regeneration, the long lasting of the regeneration potential of calli after a long 
period on maintenance media (figures 2 and 3 ) was observed. MS (5) medium confirmed it's toxicity for cell culture; because at the first week, about $80 \%$ of calli deriving from MS $(1.1 .2,5)$ and N6 (1.100.25) regenerated plants versus 10 $\%$ from MS (5). For more than $70 \%$ of calli, 7 days were enough to regenerate plant (figure 3) ; so, P. glaucum cells moved easily from non-differentiated stage to differentiated one. The number of regenerated plants per callus increased through subcultures and about 4 plants were frequently observed by subculture. So, plant regeneration should be by waves of many cell layers at different stage of development. Each layer could be constituted by many embryos. Thus, the small number of regenerated plants by wave could be due to the diferent physiological development stage of these embryos. So, the synchronized development of cells can be applied to small groups of embryos in a given callus.

On wheat, Kao (1977) noticed a variation of chromosome number after 14 months of culture on medium containing $5 \mathrm{mg}$ of $2,4 \mathrm{D}(2 \mathrm{n}-1=27)$. Karp et al (1987) and Winfield et al (1993) confirmed this variation for five species of Triticum and the negative influence of high concentrations of 2,4D on plant regeneration.
Concerning the fertility of regenerated plants, control and regenerated plants were not significantly different. The important number of seeds obtained by spike was a trump for offsprings and thus genes in stable transformation studies.

\section{CONCLUSION}

In conclusion, the fertility of regenerated plants achieved in vitro shoot apex culture study. After immature embryos (Vasil, 1981 ; 1982 ; 1987), it appears that shoot apex of $P$. glaucum was a new appropriate tool in tissue culture regarding biotechnology experiments for many reasons :

- shoot apex was available any time and could be used to initiate embryogenic callus ;

- shoot apex embryogenic calli rate was far superior to flowering immature embryos ;

- with maintainance media found, green plants could still be regenerated over 12 or 15 months after callus initiation ;

- cultured in the condition described by Ong (1979) and Tiecoura (1995), regenerated plants were fertile. 


\section{ACKNOWLEDGEMENTS}

This work was supported by a grand from F.R.F.C. (2.4518.93) and Côte d'Ivoire (C.N.O.B.). The authors are grateful to Prs Aké S. and Mondeil F. for a helpful advice. We also thank M. Delens for important technical assistance.

\section{REFERENCES}

BOTTI (C.) and VASI (I. K.) I. 1983. Plant regeneration by somatic embryogenesis from parts of cultured mature embryos of Pennisetum americanum (L.) K. Schum. Z. Pflanzenphysiol, 111 : 319-325.

CHIN-YI (L.) and VASIL (I. K.) . 1981. Somatic embryogenesis and plant regeneration from freely-suspended cells and cell groups of Panicum maximum Jacq. Ann. Bot. 48 : 543-548.

CHU (C. C.). 1978. The N6 medium and its aplications to anther culture of cereal crops. In «Proceedings of symposium on Plant Tissue Culture» Science Press, Peking pp. 43-50..

DALE (P. J.). 1977. Meristem tip culture in Lolium, Festuca, Phleum and Dactylis. Plant Science Letters, $9: 333-338$.

DALE (P. J.) and DEAMBROGIO (E.) . 1979. A comparision of callus induction and plant regeneration from different explants of Hordeum vulgare.Z. P flanzenphysiol, 94 : 65-77.

HAYDU (Z.) and VASIL (I. K.) . 1981. Somatic embryogenesis and plant regeneration from leaf tissues and anthers of Pennisetum purpureum. Theor. Appl. Genet. 59 : 269273.

KAO (K. N.). 1977. Chromosomal behaviour in somati chybrids of soybean-Nicotiana glauca. Mol.Gen. Genet. 150 : 225-230.

KARP (A.), WU (Q. S.), STEELE (S. H.) and JONES (M. G. K.). 1987. Chromosome variation in dividing protoplasts and cell suspensions of wheat. Theor. Appl. Genet.74 : 140-146.

KOBLITZ (H.) and SAALBAACK (G.) . 1976. Kalluskulturen aus apicalmeristemen von Gerste (Hordeum vulgare). Biochem. Physiol. Pflanz. 170 : 97-102.
LAMBÉ (L.), MUTAMBEL (H. S. N.), DELTOUR (R.) and DINANT (M.). 1999. Somatic embryogenesis in pear millet (Pennisetum glaucum) : Strategies to reduce geno-type limitation and to maintain long-term totipotency. Plant cell, Tissue and Organ Culture, 55 : 23-29.

MURASHIGE (T.) and SKOOG (F.) . 1962. A revised medium for rapid growth and bioassays with tobacco tissue cultures. Physiol. Plant. $15: 473-497$.

NAYAK (P.) and SEN (S. K.). 1989. Plant regeneration through somatic embryogenesis from suspension cultures of a minor millet, Paspalum scrobiculatum. Plant Cell Reports, 8 : 296-299.

ONG (C. K.) and EVERAD (A.) . 1979. Short day induction of flowering in pear millet (Pennisetum typhoi-des) and its effet on plantmor-phology. Expt.1 Agric. 15 : 401410.

OZIAS (A. P.) and VASIL (I. K.). 1982. Plant regeneration from cultured immature embryos and inflorescences of Triticum aestivum : evidence for somatic embryogenesis. Protoplasma, 115 : 104-113.

RAJASEKARAN (K.), HEIN (M. B.), DAVIS (G. C.), CARNES (M. G.) and VASIL (I. K.). 1987. Endoge-nous growth regulators in leaves and tissue cultures of Pennisetum purpureum Schum. J. of Plant Physiol.130 : 13-25.

TIÉCOURA (K.) 1995. Etude de la régénération de plantes à partir de cals embryogènes, et du transfert de gènes étrangers chez Pennisetum glaucum. PhD Thesis, University of Liège, $165 \mathrm{p}$.

VASIL (I. K.) 1987. Developing cell and tissue culture systtems for the improvement of cereal and grass crops. J. Plant. Physiol. 128 : 193-218.

VASIL (V.) and VASI (I. K.)L. 1981. Somatic embryogenesis and plant regeneration rom tissue cultures of Pennisetum americanum, and $P$. americanum $X P$. purpureum hybrid. Amer. J. Bot. 68 : 864872.

VASIL (V.) and VASIL (I. K.) . 1982 a. The ontogeny of somatic em-bryos of Pennisetum america-num L.K. Shum.I. In cultured immature embryos. Bot. Gaz. $143: 454-465$.

VASIL (V.) AND VASIL (I. K.) . 1982 b. Characterization of an embryo-genic cell suspension culture derived from cultured inflorescences of Pennisetum americanum (pear millet, Gramineae). Amer. J. Bot. 69 : 1441-1449. 
WINFIELD (M.), DAAVEY (M. R.) AND KARP (A.). 1993. A comparision of chromosome instability in cell suspension of diploid, tetraploid and hexaploid wheats. Heredity, $70: 187-194$.
YAO (K. N.). 1998. Etude de l'effet de l'acide phenoxyacetique et de l'hybrolysat de caseine sur l'ame-lioration du taux de regeneration de plantules issues de la culture d'anthères chez le riz. Univ. de Cocody/ Mémoire de DEA, $44 \mathrm{p}$. 

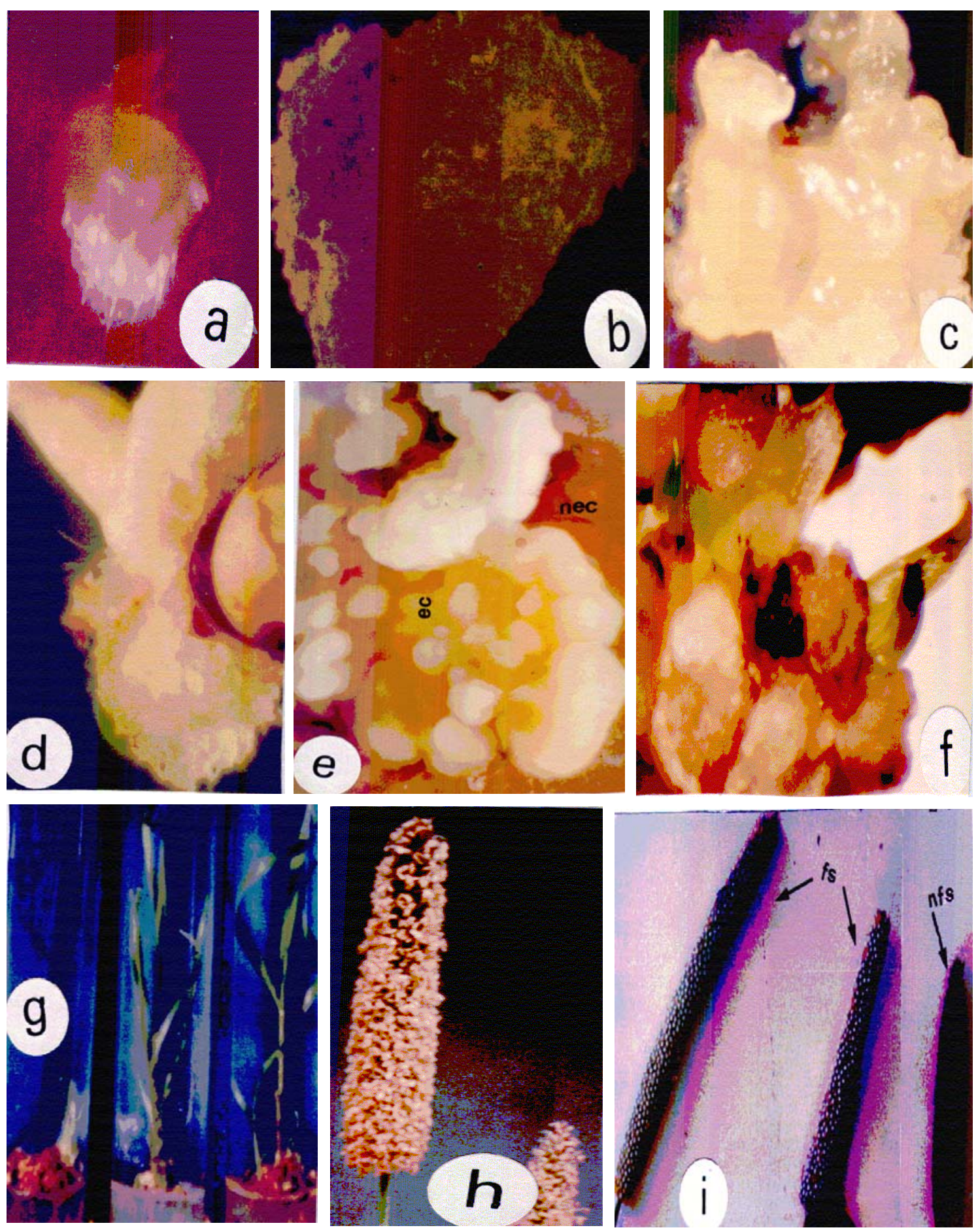

Figure 4 : Somatic embryogenesis and fertile plant regeneration with Pennisetum glaucum. a. Excised shoot apex ( $G: 56 \mathrm{x}$ ), b. Root callus ( $G: 12 x)$, c. Excised apex callus ( $G: 27 x)$ : the callus is totally embryogenic, $d$. Callus induced from seed $(G: 1,25 x)$, e. callus mixture of seed ( $(\mathrm{f}: 12 \mathrm{x})$ : embryogenic callus $(\mathrm{ec})$ and non-embryogenic callus (nec), f-g. Plant regeneration: organogenesis (f) $(G: 12 x)$ and Regenerated plants (g) (G:6x), h. Regenerated plant flowering $(\mathrm{G}: 6 \mathrm{x})$,

i. Regenerated plant fertility: fertil ( $f e$ ) and nonfertil (nfe) spike (G:6x). 